\title{
An Eco-friendly Route to Synthesis of Quinolines
}

\author{
A.D. Mishra* \\ Department of Chemistry, Tribhuvan University, P.N. Campus, Pokhara, Nepal \\ E-mail:mishraad05@hotmail.com
}

\begin{abstract}
Some 2-hydroxy-4-methyl-6- substituted quinoline derivatives have been synthesized in an environmentally benign method from easily available 4-substituted anilines and $\beta$-Ketoesters, under ordinary conditions. The reactions were catalyzed by aluminium chloride to afford excellent amount of the products. The usage of hazardous acids, bases and solvents have been avoided in different steps of the reactions completely, which has made this synthetic method one step advance to the existing methods.
\end{abstract}

Keywords: Quinolines, $\beta$-ketoesters, environmentally benign, hazardous solvents, aluminium chloride, bioactive heterocycles, cyclisation.

\section{Introduction}

Quinolines are pharmacologically important compounds which cover diverse applications as antibacterial, antiviral and antifungal agents ${ }^{1-3}$. Several methods have been reported ${ }^{4-6}$ for the synthesis of quinoline derivatives which suffer from various problems like, usage of hazardous chemicals, application of poisonous and expensive solvents, less common catalysts, drastic reaction conditions, longer reaction time period, multistep synthesis and difficult work-up. These synthetic drawbacks have been overcome by developing this eco-friendly method ${ }^{7,8}$. The synthesis of quinoline derivatives has gained the interest for their therapeutic chemistry ${ }^{9,10}$.

Synthesis of several quinoline derivatives have been reported under different conditions and catalytic influence ${ }^{11-13}$. The limitations and difficulties of those methods have been eliminated by using aluminium chloride as an acidic catalyst, which is easily available, less hazardous and recyclable. Bronsted acid and several Lewis acids have been reported to be used for the synthesis of quinolines ${ }^{14,15}$, yet they suffer from multiple practical problems. Thus the demand of eco-friendly and environmentally benign method ${ }^{16}$ for the synthesis of quinolines is fulfilled by synthesizing some qunoline derivatives under the catalytic influence of aluminium chloride. This method is expected to be a novel and efficient procedure for the synthesis of pharmacologically important quinoline derivatives. Aluminium chloride and ethanol used as catalyst and the solvent respectively can be recycled which saves the over use and misuse of the chemicals as well.

\footnotetext{
${ }^{*}$ Corresponding author
} 


\section{Experimental Methods}

The reactions were carried out in RB flask fitted with air condenser. Calibrated magnetic stirrers were used for refluxing the reaction mixture ${ }^{17}$. All the melting points were determined on a Thomas Hoover melting point apparatus and are uncorrected. The synthesized quinoline derivatives were characterized by IR and ${ }^{1} \mathrm{H}$ NMR spectroscopic analysis. IR spectra were recorded on FT Hitachi R-600 instrument using $\mathrm{KBr}$ pellets and the ${ }^{1} \mathrm{H}$ NMR spectra were recorded by using $\mathrm{CDCl}_{3}$ solvent on a Brucker $300 \mathrm{MHz}$ spectrometer with tetramethylsilane as an internal standard. The progress of the reactions was monitored by thin layer chromatography using silica gel 60-F 254 plates. The chemicals used were purchased from S D Fine Chemicals Comp. Ltd.

Scheme 1

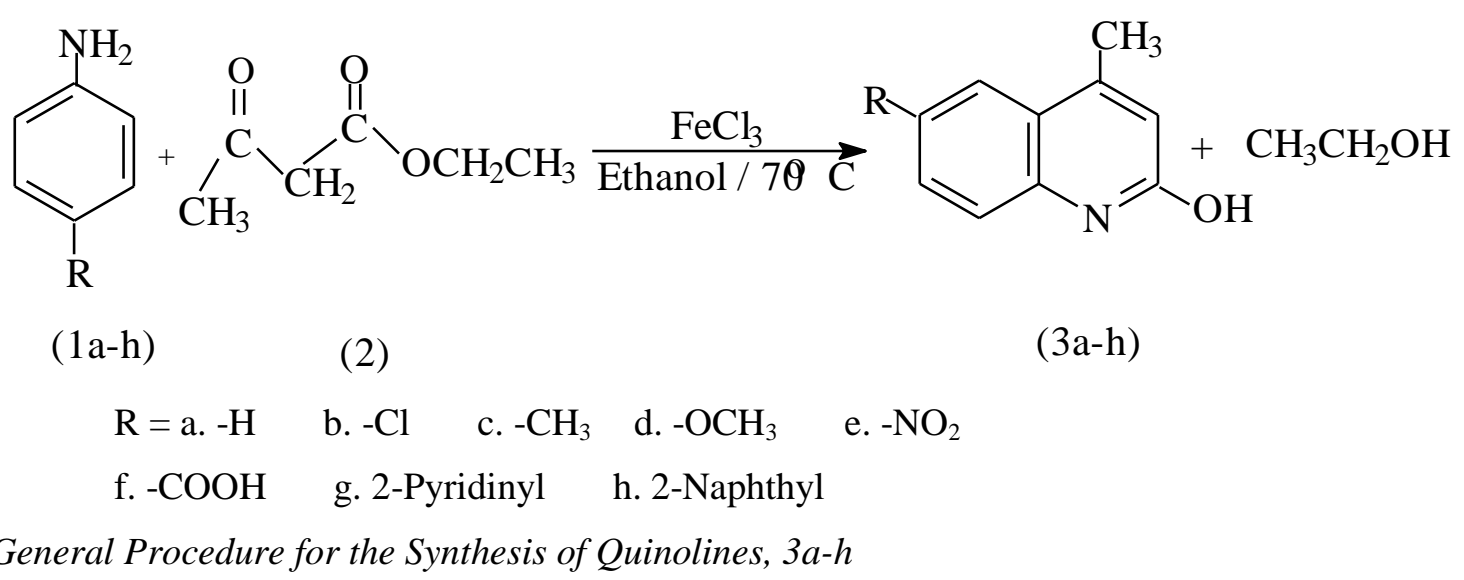

An equimolar amount ( 0.01 mole) of 4 - substituted anilines (1a-h) and ethyl acetoacetate (2) was mixed with $20 \mathrm{ml}$ of ethyl alcohol in a round bottom flask of capacity $100 \mathrm{ml}$ followed by the addition of $1 \mathrm{gm}$ of aluminium chloride to the resulting reaction mixture (Scheme 1 ). Then the reaction mixture was stirred on magnetic stirrer at $70^{\circ} \mathrm{C}$ for the time period mentioned (table 1). After the completion of the reaction as monitored by thin layer chromatography, the content was filtered and the crude product was subjected to purification by column chromatography using a mixture of ethyl acetate and n-hexane in 1:4 ratios as eluent to yield the respective 2-hydroxy- 4-methyl-6-substituted quanolines (3a-h). Solid quinolines were obtained by removing the solvents through distillation under reduced pressure and re-crystallised in ethanol. The structure of the quinolines thus obtained was confirmed by their spectral analysis (Table2).

\section{Results and Discussion}

Various aromatic amines (1a-h) were reacted with ethylacetoacetate (2) in presence of catalytic amount of aluminium chloride to afford 2-hydroxy-4-methyl-6-substituted quinolines (3a-h) in excellent yield of 70 to $90 \%$ (table 1). The cyclisation completed within time period of 1.05 to 1.35 hours (table 1). Presence of electron withdrawing groups on aromatic amines has 
caused increase in the reaction time period than the electron releasing groups. Similarly, the presence of heavier aromatic groups also has increased the time period for cyclisation period. The melting points of all the synthesized quinoline derivatives range in between $212^{\circ} \mathrm{C}$ to 297 ${ }^{\circ} \mathrm{C}$.

Table 1: Reaction time and yield of quinolines, 3a-h

\begin{tabular}{|c|c|c|c|c|}
\hline Comp no. & Value of $\mathrm{R}$ & $\begin{array}{c}\text { Reaction } \\
\text { time(hrs) }\end{array}$ & Yield (\%) & M.P. $\left({ }^{\circ} \mathrm{c}\right)$ \\
\hline $3 \mathrm{a}$ & $\mathrm{H}$ & 1.05 & 90 & 212 \\
\hline $3 \mathrm{~b}$ & $\mathrm{Cl}$ & 1.25 & 78 & 265 \\
\hline $3 \mathrm{c}$ & $\mathrm{CH}_{3}$ & 1.25 & 82 & 242 \\
\hline $3 \mathrm{~d}$ & $\mathrm{OCH}_{3}$ & 1.20 & 87 & 250 \\
\hline $3 \mathrm{e}$ & $\mathrm{NO}_{2}$ & 1.35 & 70 & 292 \\
\hline $3 \mathrm{f}$ & $\mathrm{COOH}$ & 1.30 & 71 & 297 \\
\hline $3 \mathrm{~g}$ & pyridinyl & 1.20 & 79 & 257 \\
\hline $3 \mathrm{~h}$ & naphthyl & 1.30 & 85 & 272 \\
\hline
\end{tabular}

The structures of the products, 3a-h, were confirmed through IR and ${ }^{1} \mathrm{H}$ NMR spectral analysis. The presence of $\mathrm{O}-\mathrm{H}$ group at $\mathrm{C}-2$ was confirmed by the appearance of IR bond at 3301 to $3308 \mathrm{~cm}^{-1}$ for various substitutions in the aromatic rings. The $\mathrm{O}-\mathrm{H}$ proton shows ${ }^{1} \mathrm{H}$ NMR signal at 3.4 to $3.7 \mathrm{ppm}$ for the quinolines, 3a-h.The cyclisation of amino group of anilines into imino group, $\mathrm{C}=\mathrm{N}$, in the quinolines, is evidenced by the observation of IR band at $1640-1646 \mathrm{~cm}^{-1}$. The C-N stretching showed the band at 1580 to $1586 \mathrm{~cm}^{-1}$, which further has confirmed the cyclisation of amino group into imino group in the aromatic system. All the substitutions on C-4 of aromatic amines were found to be retained at C-6 position in the synthesized quinolines by spectral data (table 2). All the methyl protons have shown chemical shift, $\delta$, at around $2.2 \mathrm{ppm}$ and the aromatic protons at 7.1 to $7.6 \mathrm{ppm}$. However the shielded proton at C-3, has appeared at 6.0 to $6.4 \mathrm{ppm}$ in various quinolines, 3a-h.

Table 2: Spectroscopic characterizations of quinolines, $\mathbf{3 a - h}$

\begin{tabular}{|l|l|l|}
\hline \multicolumn{1}{|c|}{ Comp no. } & \multicolumn{1}{|c|}{ IR, $v,\left(\mathrm{~cm}^{-1}\right)$} & \multicolumn{1}{c|}{$\mathrm{H}^{\mathrm{N} M R}, \delta,(\mathrm{ppm})$} \\
\hline $3 \mathrm{a}$ & $\mathrm{O}-\mathrm{H}(3302)$ & $2.10\left(\mathrm{~s}, 3 \mathrm{H}, \mathrm{CH}_{3}\right), 6.0(\mathrm{~S}, 1 \mathrm{H}, \mathrm{CH})$, \\
& $\mathrm{C}-\mathrm{O}(1287)$ & $3.6(\mathrm{br}, 1 \mathrm{H}, \mathrm{OH}), 7.4(\mathrm{~m}, 4 \mathrm{H}, \phi)$ \\
& $\mathrm{C}=\mathrm{N}(1642)$ & \\
& $\mathrm{C}-\mathrm{N}(1582)$ & \\
\hline $3 \mathrm{~b}$ & $\mathrm{O}-\mathrm{H}(3301)$ & $2.2\left(\mathrm{~s}, 3 \mathrm{H}, \mathrm{CH}_{3}\right), 6.1(\mathrm{~S}, 1 \mathrm{H}, \mathrm{CH})$, \\
& $\mathrm{C}-\mathrm{O}(1285)$ & $7.3(\mathrm{~S}, 1 \mathrm{H}, \mathrm{CH}), 3.5(\mathrm{br} .1 \mathrm{H}, \mathrm{OH})$, \\
\hline
\end{tabular}




\begin{tabular}{|c|c|c|}
\hline & $\begin{array}{l}\mathrm{C}=\mathrm{N}(1640) \\
\mathrm{C}-\mathrm{N}(1580) \\
\mathrm{C}-\mathrm{Cl}(880)\end{array}$ & $7.2(\mathrm{~m}, 3 \mathrm{H}, \phi)$ \\
\hline $3 c$ & $\begin{array}{l}\mathrm{O}-\mathrm{H}(3305) \\
\mathrm{C}-\mathrm{O}(1290) \\
\mathrm{C}=\mathrm{N}(1645) \\
\mathrm{C}-\mathrm{N}(1586)\end{array}$ & $\begin{array}{l}2.2\left(\mathrm{~s}, 3 \mathrm{H}_{1} \mathrm{CH}_{3}\right), 2.4\left(\mathrm{~s}, 3 \mathrm{H} \mathrm{CH}_{3}\right), \\
6.1(\mathrm{~s}, 1 \mathrm{H}, \mathrm{CH}), 3.7(\mathrm{br}, 1 \mathrm{H}, \mathrm{OH}), \\
7.3(\mathrm{~m}, 3 \mathrm{H}, \phi)\end{array}$ \\
\hline $3 d$ & $\begin{array}{l}\mathrm{O}-\mathrm{H}(3303) \\
\mathrm{C}-\mathrm{O}(1286) \\
\mathrm{C}=\mathrm{N}(1640) \\
\mathrm{C}-\mathrm{N}(1583) \\
\mathrm{N}=\mathrm{O}(1602)\end{array}$ & 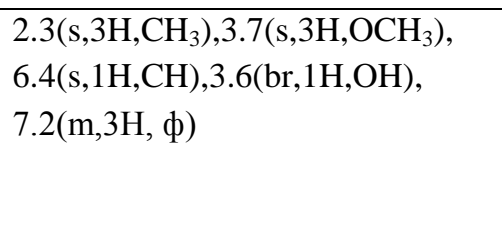 \\
\hline $3 e$ & $\begin{array}{l}\mathrm{O}-\mathrm{H}(3308) \\
\mathrm{C}-\mathrm{O}(1292) \\
\mathrm{C}=\mathrm{N}(1646) \\
\mathrm{C}-\mathrm{N}(1586) \\
\mathrm{C}=\mathrm{O}(1710)\end{array}$ & $\begin{array}{l}\left.\text { 2.2(s,3H, } \mathrm{CH}_{3}\right), 6.4(\mathrm{~s}, 1 \mathrm{H}, \mathrm{CH}) \\
3.4(\mathrm{br}, 1 \mathrm{H}, \mathrm{OH}), 7.3(\mathrm{~m}, 3 \mathrm{H}, \phi)\end{array}$ \\
\hline $3 \mathrm{f}$ & $\begin{array}{l}\mathrm{O}-\mathrm{H}(3308) \\
\mathrm{C}-\mathrm{O}(1292) \\
\mathrm{C}=\mathrm{N}(1646) \\
\mathrm{C}-\mathrm{N}(1586) \\
\mathrm{C}=\mathrm{O}(1710)\end{array}$ & 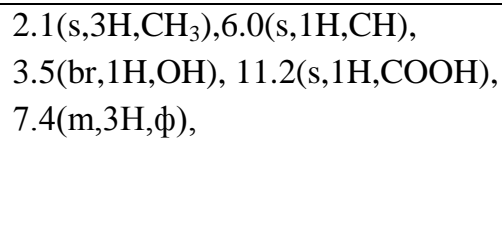 \\
\hline $3 g$ & $\begin{array}{l}\mathrm{O}-\mathrm{H}(3307) \\
\mathrm{C}-\mathrm{O}(1294) \\
\mathrm{C}=\mathrm{N}(1646) \\
\mathrm{C}-\mathrm{N}(1584)\end{array}$ & $\begin{array}{l}\text { 2.2(s,3H,CH} 3), 6.2(\mathrm{~s}, 1 \mathrm{H}, \mathrm{CH}) \\
3.6(\mathrm{br} .1 \mathrm{H}, \mathrm{OH}), 7.6(\mathrm{~m}, 7 \mathrm{H}, \phi)\end{array}$ \\
\hline $3 \mathrm{~h}$ & $\begin{array}{l}\mathrm{O}-\mathrm{H}(3307) \\
\mathrm{C}-\mathrm{O}(1294) \\
\mathrm{C}=\mathrm{N}(1646) \\
\mathrm{C}-\mathrm{N}(1584)\end{array}$ & $\begin{array}{l}2.3\left(\mathrm{~s}, 3 \mathrm{H}, \mathrm{CH}_{3}\right), 6.3(\mathrm{~s}, 1 \mathrm{H}, \mathrm{CH}) \\
3.6(\mathrm{br}, 1 \mathrm{H}, \mathrm{OH}), 7.7(\mathrm{~m}, 10 \mathrm{H}, \phi)\end{array}$ \\
\hline
\end{tabular}

\section{Conclusion}

The synthesis has afforded chemotherapeutically useful 2-hydroxy-4-methyl-6-substituted quinoline derivatives, starting from 4-substituted anilines and ethylacetoacetate within shorter reaction time and excellent yield at ordinary reaction conditions. The usage of hazardous acids and the bases have been avoided. Hence this organic synthesis can be adopted for eco-friendly and environmentally benign synthesis for chemotherapeutically important quinoline derivatives. Aluminium chloride and ethanol used as catalyst and the solvent can be recycled in this synthetic procedure which is one step advance in terms of material and environmental concerns. 


\section{Acknowledgement}

The author is thankful to the Department of Chemistry, P.N. Campus, Pokhara, for providing available laboratory facilities for the synthesis of the mentioned compounds. The Research Division, P.N. Campus, Pokhara, deserves thanks for providing research grants for conducting this research work. Sincere thanks are due to Green Chemistry Laboratory, Department of Chemistry, University of Delhi, for extension of co-operation regarding the characterization and spectral analysis of the compounds.

\section{References}

1. B. Jaing and S.Singy, J. Org. Chem., 2002, 67, 9449.

2. A. Areadi, M. Chiarini, and F. Marinelli, Synthetic letters, 2003, 203,621.

3. M. Kidwai, V. Bansal, A. Kumar and S. Mozumdar, Green Chem., 2007, 9,742.

4. A.D. Mishra, J. Nepal Chem. Soc., 2009, 24, 49.

5. R .Ghosh, Indian J. Chem., 2001, 40B, 550.

6. M .Kidwai, V.Bansal, A. Saxena, and A. Mozumdar, Tetrahedron Lett., 2006, 47, 8049.

7. A .Walser, T.Flynal and R. Fryer, J. Heterocyclic Chem., 1975, 12, 737.

8. F. Delmas, A.Avellaneda, M. Robin, and J.P. Galy, Eur. J. Med. Chem., 2004, 39, 685.

9. M. Kidwai, and V. Bansal, Lett. Org. Chem., 2007, 4, 519.

10. N. K. Wadoker and M. A .Dhiman, Indian J. Chem., 2001, 40B, 636.

11. S .H. Joshi, and M. K. Thaker, Indian J. Chem., 2005, 44B, 410.

12. H. Joshi, P. Upadhayaya, D. Karia and A. J. Baxi, Eur. J. Med. Chem., 2000, 38,837.

13. M. Amir, S .A. Javed and H. Kumar, Indian J. Chem., 2007, 46B, 1014.

14. G. Maiti, and P. Kundu, Tetrahedron Lett., 2006,47,1402.

15. M. Kidwai, P. Mishra, and R.K. Bhushan, Polyhedron, 1999,18,2641.

16. D. Dhambi, and D. Sharma, Indian J. Chem., 2009,48,1006.

17. A.D. Mishra, J. Nepal Chem. Soc., 2010, $25,83$. 